\title{
A STUDY OF THE TURBULENCE OF THE GLOBAL ECONOMY IN RESPECT TO DESIGN INDUSTRY OF FASHION AND TEXTILES POST COVID -19
}

\author{
Tamoghna Mandal \\ Department of Fashion Technology \\ Amity University, Kolkata, West Bengal, India
}

\begin{abstract}
A sudden outbreak of a new virus across the globe also known to be named COVID-19, has terrified the whole world and crippled the global economy and disturbed the existence of several economic and physical sustainability. The disease was first identified in last year December 2019 in Wuhan, China and swiftly brought fear and devastation which naturally began to upsurge the global economy to its maximum. Since then, the disease has spread more than 199 countries and territories currently infecting $\mathbf{5 , 4 6 , 9 3 4}$ individuals (number will vary). The fatalities from this disease stand at 35,004 (number will vary). Given the huge number of fatalities and sustained risk of further global spread, the World Health Organization (WHO) declared the disease a pandemic on 11 March 2020. This paper will study the effect and contingencies the virus had created so far across the world and how the Global Economy along with the Fashion and Textile Industry has been affected so far, and what precautionary steps it can take in the future from now to keep measure for all variant consumers
\end{abstract}

Keywords - Impact of Covid-19, GDP depreciation, China's multi challenged position, Impact on the Global Economy, Impact of Brands, Subsequence in Textile and Fashion Industry, India's step-in fighting corona, Contingency plans

\section{INTRODUCTION}

The pandemic outbreak has not been for the first time in the course of history. There have been several cases in the past 400 years and every time it had marked a deep scar in the mind of the people. People of various countries had been exposed to several deadly pandemics, such as the Black Death, Spanish flu, and human immunodeficiency virus/acquired immune deficiency syndrome (HIV/AIDS) over the years which brought massive casualties and took several years for the mankind to live a normal life ((Pandemics : Risk Impacts and mitigation, 2007 ). These pandemics are large scale outbreaks of infectious diseases that increase the death rate over a larger populated area causing consequential damage and hindrance to the economy concerning socio-economic and political chaos. Over the past few decades, the many root causes of this increased contagious diseases had been due to integration, urbanization, traveling, uncontrolled and cannibalistic eating habits of few states, and exploitation to the natural environment which in future will likely to increase (Ethical and Legal Considerations in Mitigating Pandemic Disease: Workshop Summary, 2007). Some previous cases of pandemic (not epidemic) cases in the last 100 years were reported as follows-:

1918- Pandemic (H1N1 virus)

1957-1958 Pandemic (H2N2 virus)

1968- Pandemic (H3N2 virus)

2009- H1N1 Pandemic (H1N1pdm09 virus)

\section{THE EFFECT OF COVID IN ASIAN COUNTRY}

India is slowly pushing to be within the world's third-highest known coronavirus burdens, with over seven lakh confirmed cases till now which is likely to increase in the coming days and has one of the world's lowest rates of testing. Since the pandemic began, tight controls on testing have made it tough for ailing patients to obtain tests, even with doctors' prescriptions. India has carried out just 7,398 tests per million of its population, compared to Brazil's 20,500 per million people, and more than 117,200 per million in the United States.

If we consider Japan as one of the most affluent, traditionally and economically developed countries in Asia, (The $3^{\text {rd }}$ largest economy just after America and China) and it was hit by the pandemic again since the last time the country had to fight with the severe consequences it had to face during the Tokyo Earthquake in 2015. The Annual income of Japan Shrank to $3.4 \%$ till March 2020 and the consumer spending dropped due to the huge Tax imposed and sudden emergency declaration. (Japan slides into recession as economy shrinks 3.4\%, 2020) 
The country had faced a certain loss and had paid a heavy price in out Olympics which was to be held in their country and preparations were going on with full enthusiasm came to a massive halt. Though the numbers of deaths were low, it hammered the business of Farms and diaries as the men and children were dependent on dairy products for their early morning office hours and schooling respectively. The obliteration to the tourism business in this month of spring which begins from late February to early April took a heavy jolt due to cancellation of international flights and the Japanese Government showed no mercy but acted vehemently to stop further spread of the life-taking virus.

\section{The Red Dragon Catastrophe}

On $31^{\text {st }}$ December 2019, China came up with the disease not only to itself but contaminated the whole world. It primarily erupted in Wuhan and within 2 months it had begun to spread its wings all over the Western European countries and after creating a havoc it moved to America and then started its dominance and destruction in the Asian Countries. The Chinese Manufacturing Base got completely destructed and many countries started planning to boycott Chinese goods and even planning to go one step further in posting an economical surgical strike to disbalance the country's export and import dependency to many European countries. This led to innumerable loss and wide upshots around and it slowly led to the economic disruption largely to the field of Travel \& Tourism, Hospitality, Hotel Industry, Restaurants, Bar, Packaged Foods.

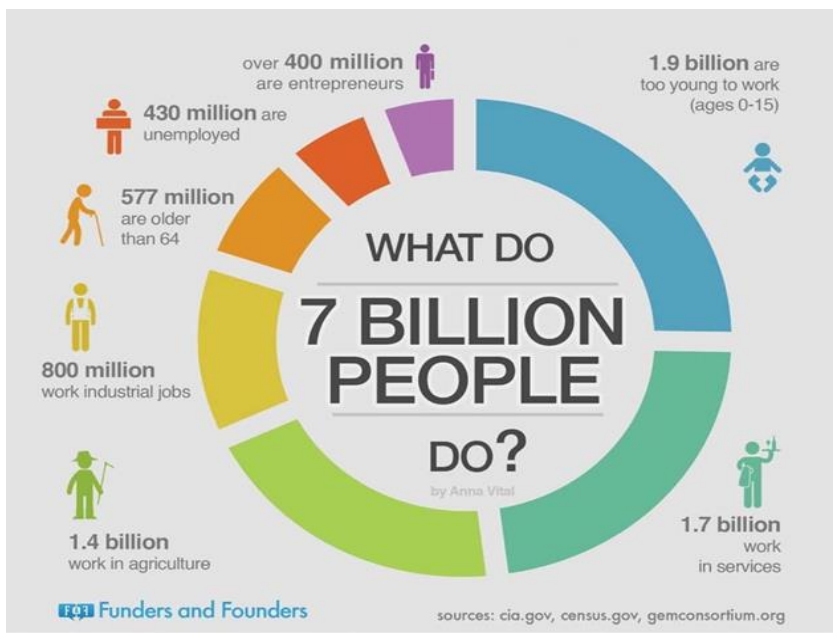

Table1.1

(https://blog.adioma.com/what-7-billion-world-populationdoes-infographic/, n.d.)

In this infographic, we see that the entire world population is 7 billion out of which 1.9 billion are mere infants or toddlers and are fully dependent on their parents or senior family members for a living. About 1.7 billion work on service sectors which is likely to get affected. 1.4 billion works on agriculture which are the highest economic factor for a country like India followed by the textile Sector which the safest sector as most of the agriculture sector, pasture and farmland are restricted to the rural areas whereas the pandemic is been observed as a happy hunting ground in the urban and high-density metropolitan cities and also considering the tier I, Tier-II cities. Over 800 million works in industrial jobs will slowly move to a standstill considering the pandemic will spread across the whole globe and disrupting the normal working procedure of service people. 577 million people are in the morbidity rate which belongs to the old people and this is where the virus COVID-19 is causing serious casualties as been notice by WHO (WORLD HEALTH ORGANISATION). Around 430 million are unemployed which is like to intensify to a staggering number of more than double (900 million) in the next 6 months considering the unattainability of vaccines and recession due to lockdown declared by most of the government of various countries across the globe by now.

Lastly, the entrepreneurs who are 400 million in numbers across the globe would likely be in the same position as the service holders freaking and having problem to figure out how to run their existing business with effective profitability considering the social distancing being the key mode to all restricts which has brought to this torrid and tumultuous situation.

This gives a piece of worried and catastrophic information that more than 5 billion people are and will live with an unknown future.

\section{Coronavirus in India: COVID-19 lockdown may cost the economy Rs 8.76 lakh crore}
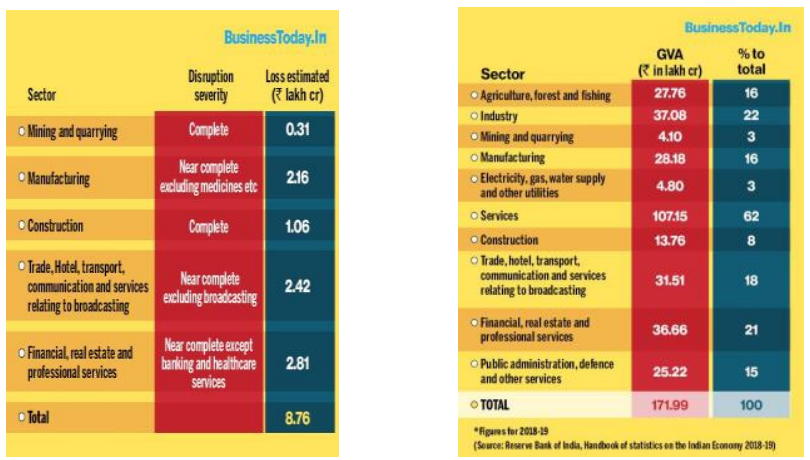

\section{Table 1.2}

(https://www.businesstoday.in/opinion/columns/coronavirusin-india, n.d.)

Here we see at the various economical Components of the Indian Economy- Gross Value Added at Basic Price in the year2011-12, at current prices. As can be seen from above, 


\section{International Journal of Engineering Applied Sciences and Technology, 2020 Vol. 5, Issue 3, ISSN No. 2455-2143, Pages 620-624 \\ Published Online July 2020 in IJEAST (http://www.ijeast.com)}

except for essential services like electricity, gas, water supply, and broadcasting, financial services (banking) and, public administration, defense, etc, all other sectors have been completely shut. The impact on agriculture, which is seasonal, cannot be ascertained exactly ((Mishra, 2020)

\section{Subsequence in the Textile Industry and Fashion Industry}

The skid of measures being taken by the government to combat the coronavirus pandemic has put textile manufacturers in a torrid situation. While on one hand, the sector is struggling to continue with its production schedule as offtake has almost come to a halt, on the other the pressure to repay its dues to banks is alarming. In January 2020 it was estimated that over an estimation -100 billion USD for India's Foreign Trade employing 45 million directly and 60 million indirectly. The textile and Fashion Industry the hardest hit industry during COVID Times since February- March 2020 finally ensuring Closing of malls and Showrooms. The textile and Clothing sectors are extremely labor and Capital intensive and there was a massive outrage regarding the migrant workers losing their jobs due to the sudden closure of all factory and industry. This led to eminent disruption in workflow and production Schedule and the Industry is currently facing its worst-ever crisis. In the export area also the COVID has taken over the key buying areas like Europe and the USA. The outbreak of this uncontrolled and contagious Virus brought to a slow but significant change in the Clothing industry which started to show its impact since January end 2020 like Closing of Denim Giant Levi's Stores in the country amid epidemic, Shanghai textile production got canceled. ((REUTERS, 2020)

\section{India's step towards fighting Corona}

For suppliers to fast fashion/mass retail, there might still be hope in the aftermath but initially, at least there will be smaller orders and very tight margins.

- Uplift of Domestic suppliers and domestic goods.

- Self-reliance, and bolstering local supply chain. The 'Atmyanirbhar Yajna' by the Prime Minister of India"

- Very low consumer sentiment = less consumption this year and to boost it the textile industry should focus on slow Fashion.

- Retailers and brands which has already halted its production lines can now focus on delayed season releases.

- The economic carnage by forced shutdowns and changes in consumer attitudes to discretionary purchases, such as clothing, may lead to the exit of weaker players which normally lives by selling its garments based on Fast Fashion.
- Experts are worried about the impact will have on the domestic apparel industry in India which has been declining since March 2020 but with the synergy of the Handloom and Khadi Sectors it can bloom by the end of 2020.

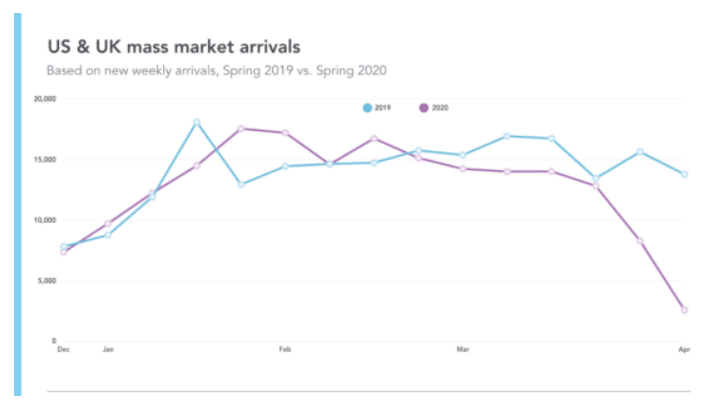

Table 1.4

This table suggests the steadfast decline of Market arrivals which has bent deeply from February till April 2020 and proceed to persist.

The Violet graph in the table 1.4 suggests the decline of Fresh Market arrivals in his year as compared to a steady rise and consistent market capture as compared to the last year (blue line). Thus, will result in a significant number of loss of a job as a mean to cut cost and will have an impact on labor market outcomes too. Loss of Income for workers along with Fall in consumption of non-essential goods like garments, salons, malls, cosmetics, and so on will further depress the economy of these areas and it will hence affect the prospect of business and economies. There will be no urgency to buy apparel as consumers are primarily focusing on groceries, medicines, and staples purchase which will lead to an uncertain economic scenario. Rise of limited product options and late \& expensive deliveries, reduction in occasions to go out $\&$ hence reduction in the need for new clothes will be seen in the next few coming months to come. Impact of COVID-19 Scenario on European and the US Apparel Market - estimates that the combined apparel consumption of EU and the US might fall to about US\$ 308 billion, 40-45\% lower than the 2020 projected consumptions. This will be a tough time for Indian and developing apparel exporters as about $60 \%$ of the country's apparel exports are destined for the EU and the US markets. (Preuss, 2020) Without fresh export orders and a restarting of the economy, many garment producers will be either forced to shut shop entirely or inflict stringent cost-cutting measures, including layoffs. CMAI anticipates as many as one crore job cuts in the textiles sector. Add to that the fact that last month, millions of migrants were compelled to flee from cities to their homes to evade death from hunger due to the plunge in economic activity.

From manufacturing through to retail, the garment industry employs close to 25 million people. As for the COVID 
Recovery, the CMAI (Clothing Manufacturing Apparel India) predicts, will take at least 10 months to a year. However, on the brighter side USA \& Japan, have decided to learn lessons from this calamity and look for alternate production sources other than China. India and Asian countries should capitalize on this situation and present itself as a credible alternative to increase its textile and apparel export share. More nationalized products to be consumed and manufactured. Khadi devolvement will be seen. More slow Fashion (Sustainable) and less Fast Fashion. Khadi and Jute production and weaving will be massive in rural areas and will be a boost to village industries. Further, manufacturers need to maximize their internal capabilities and focus on building their efficiencies if they want to emerge as a better option than competitors like Bangladesh, Vietnam, and Cambodia. We round up how the outbreak has spotlighted sustainability and the direction for a greener future post-pandemic. They must also incorporate digital strategy in the buying process. They should also think about markets other than the US \& Europe such as Japan and South Korea. The biggest shifts in fashion have historically not come from runway trends but followed events such as wars that disrupt society on a huge scale, says Kimberly Chrisman-Campbell, a fashion historian and author of Worn on This Day: The Clothes That Made History.

\section{A new wave of Paradigm Shift}

Men's Fashion week has been called off at the beginning of this year due to the COVID outbreak and Fashion weeks like Milan and Paris remain unpredictable. There is a certain lack of Eco credentials as a buyer must travel to certain cities for Fashion seasons in a year. This cancellation of shows has slowed down the Fast Fashion market and will slowly give rise to the Slow Fashion Sustainable market of Handloom fabrics and Natural Dyes which is, in turn, saving the World in less consumption of Global Carbon emission. In 2018, around 2,41,000 tons of CO2 got emitted which was equivalent to the Annual emission of Burma (Table 1.5). Tokyo, Shanghai, and Moscow had already had a digital transition of their shows showing online collection thorough live or prerecorded media which attracted 2.5 million viewership in Shanghai and 50 lakh viewership for the $1^{\text {st }}$ Day in Moscow. Virtual Showrooms, digitally produced samples, and Digital ad campaigns will be the new shift in Fashion interaction.

Sustainable Fashion will be the new shift to save Nature from such a disastrous situation. According to the United Nation, the Apparel Industry accounts for $6 \%$ to $10 \%$ of the world's greenhouse emission. We have now seen more clearer skies, natural habitat and such self-quarantine measures taken by us have also led the carbon emission Fall to $25 \%-35 \%$ Worldwide.

The textile industry will be making serious amendments in developing garments and fabrics or fibers which has inbuild Hygiene textile technology with other essential properties like anti-pilling, Hydrophilic, Water repellents Anti-Viral, Anti
Bacteria. There are few noble proceedings in the Garment manufacturing industry to make up for the severe loss and job loss in the crisis. Remake a non-profitable organization launched a pay up a petition calling few brands like Marks and Spencer, Inditex, PVH Corp. who owes more than USD 3 billion in future orders for garment factories who are suffering the most due to factory closure like India, Bangladesh, Vietnam, Cambodia to continue paying their suppliers for orders already in production. Postpone of orders rather than cancellation of orders to the deliveries already been given is always a better idea. ( (IIlchi, 2020) New concepts that have already started floating in the Fashion and Textile market such as_- "BUY LESS BUY BETTER" will be the new way of spending on clothes and clothing brands post COVID-19. This will surely give rise to the love for nature and the consumer will be more addicted and fenced to go for eco-friendly products and materials. For example, "Yulex" which is sustainably green plant-based fiber can be a sure substitute to Neoprene which will save $80 \%$ emission of Co2. Recycling and Upcycling old Fashion products and dead stocks are also a convincing plan to excite the consumers for something new. Already there have been several impetuses on Mask making and PPE (Personal Protective Equipment) which is satisfying the employment concern of many people in the garment industry as thereto are the most indispensable need of the moment for both health sector and common Consumer Sector. Some of the Companies have started funding and Donating mask for a good cause and support their brand image. (Sutton, 2020)

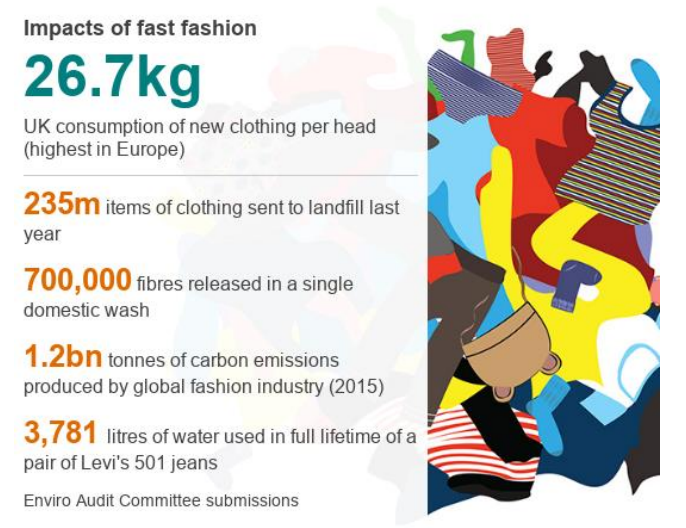

This table shows the impact of the Fast Fashion as per UK consumption of new Clothing and how nature is polluted with severe Carbon emission due to the toxic waste produced from these manufactured garments.

\section{CONCLUSION}


The whole Global Economy will now see a new chapter post COVID and it will take consumable amount of time to settle economically, financially and psychologically after this insurmountable loss which the world is facing upstage, and it may take couple of years for the people to be back at their workplaces with a normal life but that won't be in a comfort Zone for now any sooner. With God's Grace somehow in the new future the World will meet a new beginning which seems a bit far considering that there have been no vaccines invented so far, to cease this COVID Virus. As the world is hoping for a brighter future we can only see how can we control our hunger and greed so that we can stop the invasion of such deadly syndromes and Diseases and able to survive and counter a better way of living without depleting the nature and its natural existence.

\section{ACNOWLEDGWMENTS}

I would like to offer my profound thanks to almighty and the Research and Publication team of Amity University Kolkata for the support and encouragement for writing this paper. I would also like to thank the reviewers for reading the manuscripts as they were available. I would appreciate such commendable time taking task within such a short span of time. The thoughts and review have been very much appreciated.

\section{REFERENCE}

1 https://www.onmanorama.com/business/news/2020/0 5/29/india-gdp-january-march-covid-impact

2 https://fashionunited.com/news/business/outlook-euand-us-apparel-consumption

3 www.businesstoday.in/opinion/columns/coronavirusin-india, n. (n.d.)

4 Pandemic : Risk Impacts and mitigation, 2007 ). . (n.d.).

5 ILlichi L. (2020, APRIL 6).

\#Pay Up Petition Calls for Major Fashion Companies to Pay Garment Factories.

6 Nonprofit Remake, more than 50 million international garment workers are negatively impacted because of COVID-19.

7 Japan slides into recession as economy shrinks 3.4\%. (2020, May 18). KYODO NEWS.
8 Mishra, H. H. (2020, MAY 28). Coronavirus in India: COVID-19 lockdown may cost the economy Rs 8.76 lakh crore; here's how. Business Today.

9 Preuss S. (2020, April 13). Outlook: EU and US apparel consumption could fall by 300 billion US dollars in 2020.

10 Sutton, S. (2020, March 28). How Your Favorite Fashion Brands Are Helping Out During the Coronavirus Pandemic. 